\title{
Study of Translation Strategies for English Version of the Diamond Sūtra from the Perspective of Skopos Theory
}

\author{
Tingting Mi
}

\author{
GRADUATE UNIVERSITY OF MONGOLIA, Ulan Bator, Mongolia. \\ tingtingmi0922@gmail.com
}

\begin{abstract}
The Diamond Sütra is written in Sanskrit originally, which was translated into Chinese afterwards. Kumarajiva's version is the most popular one. Most of the English versions of the Diamond Sütra that are widely spread in western countries are all translated according to Kumarajiva's Chinese version. This thesis aims to make comparative studies on the Chinese version and English versions to summarize the words translation techniques, explore the factors that affect the translators' translation.
\end{abstract}

Keywords: The Diamond Sütra, A. Charles Muller, Kumarajiva, translation.

\section{Introduction}

The Diamond Sütra, also known as the Diamond Prajna Paramita Sūtra, is the essence of Mahāyāna Buddhism prajna sūtra. Its Sanskrit name is vajracchedikā nāma triśatikā prajñāpāramitā. It plays an important role in the Buddhist and secular circles, and has a great influence on the development of Zen Buddhist and neo-Confucianism in the song and Ming dynasties. In Chinese culture, the Diamond Sütra is a Buddhist sūtra with great influence. Over the past thousand years, so many people have become enlightened because of the Diamond Sütra. Nan huaijin (a contemporary Chinese poet, Buddhist scholar, educator, disseminator of ancient Chinese culture) once said, "The Diamond Sütra transcends all religions and contains all religions." Wu zetian, the empress of China, once praised this sūtra: "It is the most profound and subtle law. Now that I have seen my troubles sustained, I wish to understand the truth and righteousness of the Tathagata."

The Diamond Sütra is mainly discusses about empty wisdom in the form of questions and answers between Buddha and his elder disciple Subhuti. It focuses on the problem that all the things in the world are not real or non-existent. It is generally believed that the former part is about non-existence of living beings, and the latter part is about non-existence of Dharma. The concept of non-existence in Buddhism is the essence of Buddhist religion. Kumarajiva was the first one who translated the Diamond Sütra from Sanskrit to Chinese.

\section{English Translation of the Diamond Sūtra}

As been mentioned above The Diamond Sūtra plays an influential role in Buddhist sūtras, there are several Sanskrit to Chinese versions, Chinese to English versions and Sanskrit to English versions of the Diamond Sütra. According to the data collected online, there are few studies on the English translation of the Diamond Sūtra, as shown in table (1).

table 1

\begin{tabular}{|c|c|c|c|}
\hline 1 & Samuel Beal & 1865 & $\begin{array}{c}\text { E. S. Beal, Vajra-chhedika, the "Kin Kong King" or } \\
\text { Diamond Sūtra, in Journal of Royal Asiatic Society, N. S. } \\
\text { I., pp.1-24, 1864-1865, from Chinese to English. }\end{array}$ \\
\hline 2 & $\begin{array}{c}\text { E.B.Cowell, Friedrich } \\
\text { Max Muller, J. Takakusu }\end{array}$ & 1894 & $\begin{array}{c}\text { DIAMOND-CUTTER, Translated by E.B. Cowell, F. } \\
\text { Max Mulller, and J. Takakusu, from Sanskrit to English. }\end{array}$ \\
\hline 3 & William Gemmel & 1912 & $\begin{array}{c}\text { William Gemmel: The Diamond Sūtra or } \\
\text { Prajna-Paramita, London, Trubner 1912, from Chinese to } \\
\text { English. }\end{array}$ \\
\hline
\end{tabular}




\begin{tabular}{|c|c|c|c|}
\hline 4 & Dwight Goddard & 1931 & $\begin{array}{c}\text { A Buddhist Bible, ed. by Dwight Goddard, Based on } \\
\text { William Gemmell's translation edited, rearranged and } \\
\text { interpreted. }\end{array}$ \\
\hline 5 & Daisetz T. Suzuki & 1934 & $\begin{array}{l}\text { The Diamond Sūtra, Daisetz T. Suzuki, Manual of Zen } \\
\text { Buddhism, 1934, pp.43-56., from Sanskrit to English. }\end{array}$ \\
\hline 6 & Hsuan Hua & 1974 & $\begin{array}{l}\text { A General Explanation: Vajra Prajna Paramita Sūtra, from } \\
\text { Chinese to English( Unknown Chinese Basis) }\end{array}$ \\
\hline 7 & Schopen Gregory & 1989 & $\begin{array}{l}\text { Studies in the Literature of the Great Vehicle: Three } \\
\text { Mahāyāna Buddhist Texts, from Sanskrit to English. }\end{array}$ \\
\hline 8 & Thich Nhat Hanh & 1992 & $\begin{array}{l}\text { The Diamond that Cuts Through Illusion, from Chinese to } \\
\text { English (unknown Chinese basis) }\end{array}$ \\
\hline 9 & Mu Soeng & 2000 & $\begin{array}{l}\text { The Diamond Sūtra: Transforming the Way we Perceive } \\
\text { the World, from Sanskrit to English }\end{array}$ \\
\hline 10 & Edward Conze & 2001 & $\begin{array}{l}\text { Buddhist Wisdom: The Diamond Sūtra and The Heart } \\
\text { Sūtra, from Sanskrit to English. }\end{array}$ \\
\hline 11 & Red Pine & 2001 & $\begin{array}{l}\text { The Diamond Sūtra: The Perfection of Wisdom; Text and } \\
\text { Commentaries, from Sanskrit to English }\end{array}$ \\
\hline 12 & $\begin{array}{l}\text { A. F. Price, Wong } \\
\text { Mou-Lam }\end{array}$ & 2004 & $\begin{array}{c}\text { The Diamond Sūtra, A. F. Price, Wong Mou-Lam, } \\
\text { Published by Kessinger Publishing, 2004, from Chinese to } \\
\text { English. }\end{array}$ \\
\hline 13 & Paul Harrison & 2006 & $\begin{array}{c}\text { Vajracchedikā-prajñāpāramitā: A New English Translation } \\
\text { of the Sanskrit Text Based on Two Manuscripts from } \\
\text { Greater Gandhara, from Sanskrit to English }\end{array}$ \\
\hline 14 & $\begin{array}{l}\text { Chung Tai Translation } \\
\text { Committee }\end{array}$ & 2009 & $\begin{array}{l}\text { The Diamond of Perfect Wisdom Sūtra, from the Chinese } \\
\text { translation by Tripitaka Master Kumarajiva }\end{array}$ \\
\hline 15 & $\begin{array}{l}\text { Plum Village and SUNY } \\
\text { Stony Brook BSPG }\end{array}$ & 2010 & $\begin{array}{l}\text { The Diamond That Cuts Throuch Illusion, Provided by } \\
\text { The Plum Village and SUNY Stony Brook BSPG }\end{array}$ \\
\hline 16 & A. Charles Muller & 2013 & The Diamond Sūtra, from Chinese to English \\
\hline 17 & Charles Luk & unknown & $\begin{array}{l}\text { The Diamond Perfection of Wisdom Sūtra, from Chinese to } \\
\text { English }\end{array}$ \\
\hline 18 & Charles Patton & unknown & The Diamond Sūtra, from Chinese to English \\
\hline 19 & $\begin{array}{l}\text { Lobsang Chunzin , } \\
\text { Michael Roach }\end{array}$ & Unknown & $\begin{array}{c}\text { The Diamond Sūtra (Tibetan-English), Lobsang Chunzin } \\
\text { \& Michael Roach, from Tibetan to English. }\end{array}$ \\
\hline
\end{tabular}


According to the table above, the author finds nineteen English versions of the Diamond Sūtra from now on. There are seven versions are translated from Sanskrit to English. At the same time, there are scholars translated the Diamond Sütra on the basis of Tibetan or English versions. There are nine versions are translated from Chinese to English, and there is only one version translated on the basis of English version.

\section{Skopos Theory}

Skopos is a Greek word for "purpose" (Nord, 2001:27). As Vermeer puts it, "any action has an aim, a purpose". Thus, the word Skopos is "a technical term for the aim or purpose of a translation" (Reiss and Vermeer, 1984:96). Vermeer founded the Skopos theory that applies the notion of Skopos to translation. In the framework of this theory, every translation is directed at an intended audience, and translation means "to produce a text in a target setting for a target purpose and target addressees in target circumstances".

\section{Words translation of the English Version of the Diamond Sūtra under the Guidance of Skopos theory}

In order to make the translation readable and acceptable, to make the reader understand the content of the original text better, directly and simply, the translator should adjust the words, sentences and paragraphs appropriately in the process of translation. By adding, deleting and transforming words, adjusting sentence patterns and paragraphs, the translator can make the translation accord with the reader. Reading habits, on the basis of maintaining the complete transmission of the original content, make it easier for readers to accept the translation and make the translation readable. Now let's set some examples of the words translation in the English version.

\subsection{Features of the Words Translation in the English Version}

In translating the Buddhist terms, A. Charles Muller has different features in the following aspects: the translation and explanations to the Buddhist terms, the length of expressions and readability of the words.

There are a lot of Buddhist terms in the Diamond Sūtra, such as the names of Buddha, Buddhist places, the states in practicing Buddhist doctrine. Such as “舍卫国”“涅 槃”“佛”“须菩提”“如来”“菩萨”“释迦牟尼”和 “世尊”, some of the terms were the transliterated Sanskrit, but some were used free translation.

Examples:

舍卫国: Śrāvastī

祇树给孤独园: Jetavana Grove
须菩提: Subhūti

佛: Buddha

世尊: the World-honored One

如来: Tathāgata

菩萨: Bodhisattva

摩诃萨: Mahasattva

The above religious names are all common to be used in sūtras, not only in Sanskrit text, but also in English text. Except for the examples above, the other Buddhist terms in the Diamond Sütra appear in different way of translation. For the names of the Buddha, the translation can be divided into three parts.

(1) Translated from Sanskrit.

(2)Sanskrit+English

(3)English

All the Buddist terms as shown in the table:

\begin{tabular}{|l|l|l|}
\hline $\begin{array}{l}\text { Buddhist Names and } \\
\text { places in Chinese }\end{array}$ & $\begin{array}{l}\text { expression in } \\
\text { English }\end{array}$ & $\begin{array}{l}\text { ways of } \\
\text { translation }\end{array}$ \\
\hline 佛 & Buddha & Sanskrit \\
\hline 比丘 & Monk & English \\
\hline 世尊 & $\begin{array}{l}\text { The } \\
\text { World-honored } \\
\text { One }\end{array}$ & English \\
\hline 须菩提 & Subhūti & Sanskrit \\
\hline 舍卫国 & Śrāvastī & Sanskrit \\
\hline 祇树给孤独园 & Jetavana Grove & Sanskrit+English \\
\hline 菩萨 & Bodhisattva & Sanskrit \\
\hline 摩诃萨 & Mahāsattva & Sanskrit \\
\hline 如来 & Tathāgata & Sanskrit \\
\hline 须陀洹 & Srota-āpanna & Sanskrit \\
\hline 斯陀含 & Sakrdāgāmin & Sanskrit \\
\hline 阿那含 & Anāgāmin & Sanskrit \\
\hline 阿罗汉 & Arhat & Sanskrit \\
\hline 燃灯佛 & $\begin{array}{l}\text { Dīpamkara } \\
\text { Buddha }\end{array}$ & Sanskrit \\
\hline 佛土 & Buddha-lands & Sanskrit+English \\
\hline 释迦牟尼 & Śākyamuni & Sanskrit \\
\hline 比丘尼 & nun & English \\
\hline 优婆塞 & Male & English \\
\hline 优婆夷 & Female & English \\
\hline 阿修罗 & Titans & English \\
\hline
\end{tabular}

As we can see from the table, for most of the Buddhist names or places A. Charles Muller expresses in Sanskrit, but some of them is expressed in English, only a few is expressed in Sanskrit plus English, such as “祇树给孤独园” is translated into "Jetavana Grove", which means the famous Buddhist holy place is located five miles outside the South Gate of Śrāvastī. Actually the Sanskrit of “祇树给孤 独园” is "Jetavanavihāra", "Grove" in English means "a small area of land with fruit trees of particular types on it", but here Charles make an abbreviation of "Jetavanavihāra", and plus the meaning of “Grove". “佛土” is also translated 
by the way of Sanskrit plus English, which means the kingdom of Buddha, the territory of Buddha, the Buddhist realm and the Buddhist temple. It refers to the place where Buddha lives or the land of Buddhism. It refers not only to the pure land, but also to the real world (filthy land) where ordinary people live. It is also called the Buddhist land.

\subsection{The Length of Expressions}

For some of the Buddhist terms, especially some terms that has adjective or adverbs in Chinese, however, A. Charles Muller's expressions are totally shorter.

阿耨多罗三藐三菩提: peerless perfect enlightenment (Chapter 2)

不可思量: be incalculable (Chapter 4)

有色: have form (Chapter 3)

清净心: pure aspiration (Chapter 10)

三千大千世界: a chiliocosm (Chapter 8)/three thousand galaxies (Chapter11)

一合相: composite (Chapter 30)

In translating Buddhist terms, A. Charles Muller uses two forms in his version that is transliterated Sanskrit or English. Without any note, omission and amplification, his translation is faithful to the Chinese text. It's the direct translation in translation studies.

Translation Techniques of A. Charles Muller's version:

(1) transliterated Sanskrit

(2) English

(3) direct translation

\section{Summary}

As a modern scholar, A. Charles Muller is interested in Mahāyāna Buddhism and pays attention to translating the Mahāyāna Buddhist Sūtras. Once he said, he had been, throughout his career, deeply involved in the work of translating classical East Asian works for the Western audience. He was really interested in and investigated the meaning and role of Mahāyāna Buddhism. He translated the sūtras for common readers, not for Buddhist professionals. Thus in his translation, except for the names of Buddhas or places, most of the Buddhist terms are in English, not in transliterated Sanskrit, which is totally convenient for understanding. Meanwhile, his translation is popular and easy to understand.

\section{References}

[1] A. F. Price, Wong Mou-Lam, The Diamond Sūtra and the Sutra of Hui-neng, Shambhala Publications, 2005.

[2] A. Charles Muller, The Diamond Sūtra, 30Jun 2019.
[3] Catford, J. C, A Linguistic Theory of Translation, Oxford University Press, 1965.

[4] Newmark Peter, A Textbook of Translation, Shanghai Foreign Language Education Press,2001.

[5] Hsuan, Hua, A General Explanation: The Vajra Prajna Paramita Sūtra, Buddhist Text Translation Society, 1974.

[6] Laurence, Venuti, Skopos and Commission in Translation Action. London: Routledge,2000.

[7] Mu, Soeng, The Diamond Sūtra: Transforming the Way We Perceive the World, Somerville: Wisdom Publications, 2000.

[8] Thich, Nhat Hanh, The Diamond that Cuts Through Illusion: Commentaries on the Prajnaparamita Diamond Sūtra, Berkeley: Parallax Press, 1992.

[9] William Germmel, The Diamond Sūtra (Chin-Kang-Ching), London: Broadway House, 1912.

[10] Nord, Christiane, Translating as a Purposeful Act-Functionalist Approach Explained. Manchester, St. Jerome Publishing Company, pp.27-28, 2001.

[11] Reiss, K. and Vermeer, Groundwork for a General Theory for Translation. Tubingen: Niemeyer, pp. 96-97, 1984.

[12] Kumarajiva, The Diamond Sūtra, Taisho Tripitaka, Vol, 8, No.235, CBETA

http://tripitaka.cbeta.org/mobile/index.php?index $=$ T08n 0235_001

[13] Nan Huai-chin, Nan Huai-chin Anthology, What does The Diamond Sütra Talk about? vol.5, 2009. 